\title{
Adherence of multiresistant strains of Klebsiella pneumoniae to cerebrospinal fluid shunts: correlation with plasmid content
}

\author{
C. D. DENOYA*, A. R. TREVISAN and J. ZORZOPULOS
}

Department of Molecular Genetics, Instituto Sidus S.A., (1876) Bernal, Provincia de Buenos Aires, Argentina

\begin{abstract}
Summary. A nosocomial multiresistant Klebsiella pneumoniae strain (KMD01) isolated from a patient with an infected ventriculoperitoneal (V-P) shunt was found to contain three plasmids of mol. wts $\left(10^{6}\right) c .85,50$ and $2 \cdot 4$. A derivative isogenic strain (KMD11) carrying only the plasmids of mol. wts $\left(10^{6}\right) 50$ and 2.4 was obtained spontaneously by plating the parent strain. The absence of the plasmid of mol. wt $85 \times 10^{6}$ in strain KMD11 correlated with an increased adherence to V-P catheters and glass surfaces, as well as autoagglutination in minimal medium. Bacterial cells containing the whole set of plasmids (strain KMD01) also showed the incorporation into the outer membrane of a new polypeptide (mol. wt, c. $41 \times 10^{3}$ ), when grown in minimal medium. The presence of this polypeptide correlated with absence of autoagglutination, as shown by strain KMD01 under these cultural conditions. These data suggest that the cell-surface characteristics in $K$. pneumoniae may be affected by the plasmid content of the strain. Since nosocomial strains of $K$. pneumoniae usually contain one or more plasmids, and strains easily exchange these extrachromosomal elements, it seems reasonable to speculate that new variants with higher V-P shunt colonisation effectiveness, like the one described in this work, may also evolve in nature.
\end{abstract}

\section{Introduction}

Permanent ventriculoatrial and ventriculoperitoneal (V-P) shunts are currently used for the treatment of hydrocephalus. Infection of the shunt and consequently induced ventriculitis is one of the most frequent complications of this surgical treatment. The temporal relation between the onset of symptoms of shunt infection and the preceding shunt surgery (insertion or revision) varies considerably from a few days to several months (Schoenbaum $e t$ $a l, 1975)$. Clinical, bacteriological and experimental evidence suggests that in most of the infections the causative organisms gain access to the shunt at the time of operation (Bayston and Lari, 1974; Schoenbaum et al., 1975). However, the pathogenic mechanisms involved in the microbial colonisation of the shunts are not yet completely known.

It has been demonstrated that bacterial adherence to epithelial-cell surfaces is an important first step in the initiation of certain infections, like those

Received 2 Apr. 1985; accepted 21 Jun. 1985.

* Present address and requests for reprints: The Public Health Research Institute of the City of New York, 455 First Avenue, New York, NY 10016, USA. occurring in the oropharynx and in the urinary tract (Fader and Davis, 1980; Ayars et al., 1982). Similarly, the adhesion of bacteria to smooth surfaces of prosthetic devices seems to be an important step in the onset of infections of these medical devices (Bayston and Penny, 1972; Christensen et al., 1983). Moreover, this property may be an important mechanism in the survival and persistence of microorganisms in an infected catheter, even after proper antibiotic therapy (Peters et al., 1982).

We have previously observed that multiresistant plasmid-containing strains of Klebsiella pneumoniae are a frequent and troublesome cause of nosocomial shunt infection in hydrocephalic patients who had cerebrospinal fluid (CSF) shunts inserted at the Children's Hospital of Buenos Aires (Denoya et al., 1981). Furthermore, we have previously analysed colonised shunts removed from infected patients by scanning electronmicroscopy, and shown that several gram-positive and gram-negative pathogens were able to stick to V-P catheters, developing microcolonies predominantly located in holes and other irregularities found in the inner surfaces of implanted shunts (Guevara et al., 1981).

The aim of this work was to examine further the 
bacterial factors that could be important in the adhesion of these pathogens to the shunt surfaces. We therefore investigated the adherence to V-P catheters in vitro of two related multiresistant plasmid-containing strains of $K$. pneumoniae.

\section{Materials and methods}

\section{Bacterial strains}

Klebsiella pnemoniae strain KMD01 was obtained from the infected CSF of a hydrocephalic child with an implanted V-P shunt. The shunt was implanted when she was 1 month old, and it had to be removed 1 year later because of infection with Staphylococcus aureus. A new shunt was implanted; this time it became infected with a nosocomial strain of $K$. pneumoniae, with an antibiogram similar to that reported for strain KMD01 (see below). Because the patient was very compromised, antimicrobial therapy was administered intramuscularly and intrathecally, without shunt replacement. After 2 weeks the patient had recovered and was discharged from the hospital. During the following year she had some nonspecific complaints such as sporadic fever, vomiting, and signs of increased intracranial pressure, until an infection became manifest again. At that time, $K$. pneumoniae strain KMD01 was isolated; it was resistant to ampicillin, cephaloridine, sisomicin, tobramycin, gentamicin, kanamycin and chloramphenicol. Because this strain was suspected to have persisted within the shunt since the time of operation, it was selected for study.

$K$. pneumoniae strain KMD11 was a spontaneous derivative of strain KMD01, isolated after in-vitro culture (see below). It had lost a cryptic plasmid of mol. wt $85 \times 10^{6}$ present in the parent strain (fig. 1).

Bacterial strains were identified by standard procedures (Isenberg et al., 1980). Antibiotic sensitivities were tested by disk diffusion (Bauer et al., 1966).

\section{Preparation and analysis of plasmid DNA}

Partially purified plasmid DNA was prepared essentially as described by Birnboim and Doly (1979). Samples of plasmid DNA were analysed by agarose-gel electrophoresis as previously described (Zorzópulos et al., 1984). Molecular mass estimates were made relative to standard plasmids: R40a, mol. wt $96 \times 10^{6}$; Rldrd19, mol. wt $62 \times 10^{6}$; and Escherichia coli V517 plasmids, of mol. wts $\left(10^{6}\right)$ 1.4-35.8 (Macrina et al., 1978) as previously described (Denoya et al., 1981).

\section{${ }^{35} S$-labelling of bacteria}

Organisms were grown in Luria-Bertani (LB) Broth containing tryptone $1 \% \mathrm{w} / \mathrm{v}$, yeast extract $0.5 \% \mathrm{w} / \mathrm{v}$ and sodium chloride $1 \% \mathrm{w} / \mathrm{v}$, at $p \mathrm{H} 7 \cdot 2$ (Maniatis et al., 1982). After overnight growth at $37^{\circ} \mathrm{C}, 1 \mathrm{ml}$ of the culture was centrifuged, and the pelleted cells were resuspended in 1 $\mathrm{ml}$ of M9 minimal medium (Maniatis et al., 1982) supplemented with glucose $0 \cdot 2 \% \mathrm{w} / \mathrm{v}$ and $1 \mathrm{~mm} \mathrm{MgSO}_{4}$; $50 \mu \mathrm{l}$ of this suspension were inoculated into $1 \mathrm{ml}$ of the same medium containing $0.01 \mathrm{mCi}$ of ${ }^{35} \mathrm{~S}$-methionine (sp.act. $1098 \mathrm{Ci} / \mathrm{mmol}$; ICN Biomedicals, Inc.) and incubated at $37^{\circ} \mathrm{C}$ with aeration provided by shaking, to an optical density at $600 \mathrm{~nm}$ of $0 \cdot 6$. The bacteria were then washed twice in Adherence Medium (AD) containing 1.2 $\mathrm{M} \mathrm{NaCl}, 0.012 \mathrm{M} \mathrm{CaCl}_{2}$, bovine serum albumin $0.04 \% \mathrm{w} / \mathrm{v}$,

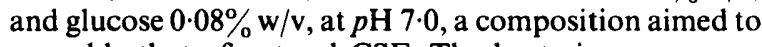
resemble that of natural CSF. The bacteria were resuspended in $200 \mu \mathrm{l}$ of AD medium and used in the adherence assays (see below). This method resulted in a specific activity of $0.005-0.02$ counts $/ \mathrm{min} /$ bacterium.

\section{Assay of adherence to $V-P$ catheters with radio- labelled bacteria}

The capacity of adherence to CSF shunts achieved by strains KMD01 and KMD11 was measured by use of ${ }^{35} \mathrm{~S}$ methionine labelled bacteria with similar specific activities. The catheters examined (Holter V-P shunts) were split longitudinally, cut into $0.5-\mathrm{cm}$ pieces, and positioned with their convex faces on a double sticky face tape attached to a millboard piece. On to the upper concave face of the catheter piece, $1.0 \times 10^{6}{ }^{35} \mathrm{~S}$-labelled bacteria $(5 \mu \mathrm{l})$ were pipetted. After incubation for $40 \mathrm{~min}$ at $37^{\circ} \mathrm{C}$ in a humid chamber, the bacterial suspension was absorbed with the border of a filter paper, and the catheter piece introduced with forceps into a 1.5-ml Eppendorf microcentrifuge tube. Usually, four similar catheter pieces were processed for each strain. One catheter piece (no. 1) was conserved without washing. Another piece (no. 2) was washed once with $1 \mathrm{ml}$ of phosphate-buffered saline (PBS) by gentle inversion of the tube three times. Piece no. 3 was washed once with $1 \mathrm{ml}$ of PBS with vigorous agitation by a vortex mixer for $5 \mathrm{~s}$. Piece no. 4 was washed five times by the washing procedure described for piece no. 3. Finally, the catheter pieces were positioned on a millboard piece, as described above, dried with an electric lamp, covered with plastic wrap, and exposed to a Kodak film for 1 or more days. The adherence capacity was evaluated from the autoradiogram by comparison of the catheter pieces submitted to the different washing procedures.

\section{Autoagglutination test}

Autoagglutination capacity of each strain was evaluated by subculturing one volume of a fresh overnight LB culture into 100 volumes of minimal Davis broth (Difco Laboratories) containing, per $\mathrm{L}, \mathrm{K}_{2} \mathrm{HPO}_{4} 7 \mathrm{~g}$, $\mathrm{KH}_{2} \mathrm{PO}_{4} 2 \mathrm{~g}$, sodium citrate $0.5 \mathrm{~g}, \mathrm{MgSO}_{4} 0.1 \mathrm{~g}$, $\left(\mathrm{NH}_{4}\right)_{2} \mathrm{SO}_{4} 1 \mathrm{~g}$, and glucose $20 \% \mathrm{w} / \mathrm{v} 20 \mathrm{ml}$. This culture was incubated at $37^{\circ} \mathrm{C}$ for $4 \mathrm{~h}$ with continuous shaking. Then the culture tubes were left to stand without shaking at room temperature for a few minutes. Autoagglutination was evaluated visually and recorded by taking photographs of a lateral or a bottom view of the tubes (figs. 4 and 5). In some experiments, bacteria were grown in LB broth until late exponential phase, washed once with minimal medium, and resuspended at a cell density of 
$4 \times 10^{8} / \mathrm{ml}$ in the same medium. The culture was further incubated for $4 \mathrm{~h}$ at $37^{\circ} \mathrm{C}$ with continuous agitation, and autoagglutination was evaluated visually as before (fig. 5).

\section{Adherence to glass surfaces}

Adherence to standard glass culture tubes was performed essentially as described by Christensen et al. (1982). Briefly, each strain was grown in LB broth at $37^{\circ} \mathrm{C}$ overnight in standard borosilicate tubes. Next morning the tubes were emptied by inversion, and adherent growth was considered to be present if a bacterial film was seen on the inner surface of the tube. Ring formation at the liquidair interface was not considered to indicate adherent growth. In some experiments the bacterial film was made more obvious by staining with trypan blue.

\section{Analysis of membrane proteins by SDS-polyacryla- mide-gel electrophoresis}

Klebsiella strains were grown in LB or in minimal Davis medium as described previously. Membrane fractions were obtained, as described by Schnaitman (1971), and membrane proteins were resolved in $10 \%$ SDS-polyacrylamide gels, as described by Laemmli (1970). Protein bands were observed after staining with Coomassie brilliant blue R250.

\section{Results}

\section{Plasmid content analysis}

The multiresistant $K$. pneumoniae strain KMD01 harbours three plasmids of mol. wts $\left(10^{6}\right) c .85,50$ and 2.4 respectively (fig. $1 \mathrm{~A}$ ). After overnight incubation of this strain at $37^{\circ} \mathrm{C}$ in LB broth, up to $5 \%$ of the cells were found to have lost the plasmid of mol. wt $85 \times 10^{6}$, among more than 300 colonies analysed by plasmid content. $K$. pneumoniae strain KMDl1 is representative of this subpopulation which has lost the large plasmid (fig. 1B). The plasmid content of strain KMD11 was found to be very stable even after more than 20 passages in vitro. Additionally, both the parent and its derivative presented similar antibiotic-resistance patterns, because the corresponding resistance markers are associated with the plasmid of mol. wt $50 \times 10^{6}$ or are located along the chromosome (Zorzópulos et al., 1984; and data not shown).

\section{Adherence to $V$-P catheters and glass surfaces}

As shown in fig. 2, K. pneumoniae strain KMD11 presented a higher capacity for adherence to the inner surface of catheters of V-P shunts in vitro than its parent strain KMD01. This figure dramatically illustrates that the derivative strain is able to persist,

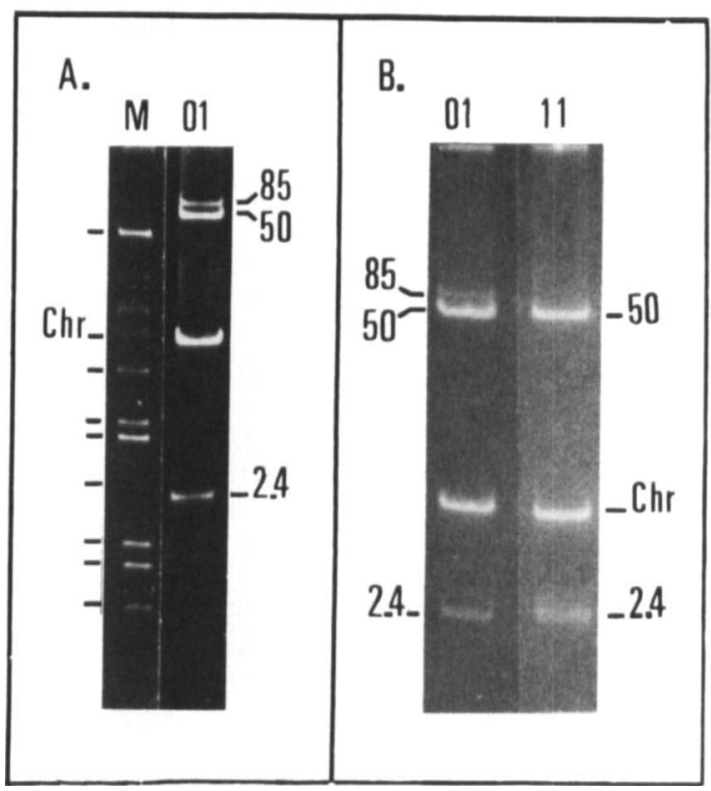

Fig. 1. Agarose-gel electrophoresis of plasmid DNA from $K$. pneumoniae strains. A: Well "0l" contained plasmid DNA from the CSF isolate, strain KMD01. Well " $M$ " contained mol. wt reference plasmids from $E$. coli strain V 517 (the positions of the reference plasmids of mol. wts $\left(10^{6}\right) 35 \cdot 8,4 \cdot 8,3 \cdot 7,3 \cdot 4,2 \cdot 6,2 \cdot 0,1 \cdot 8$ and 1.4 are indicated on the left border of the figure). B: Well " 01 " contained plasmid DNA from a colony of $K$. pneumoniae strain KMD01 isolated in vitro, and well " Il" from a colony of $K$. pneumoniae strain KMD11 isolated in vitro which lacks the large plasmid. "Chr" is the region where chromosomal DNA fragments migrate. Electrophoreses were performed at $150 \mathrm{~V}$ for $3 \mathrm{~h}$; agarose-gel concentrations were $0.8 \% \mathrm{w} / \mathrm{v}(\mathrm{A}), 0.6 \% \mathrm{w} / \mathrm{v}(\mathrm{B})$. Mol. wts $\left(10^{6}\right)$ of plasmids are indicated.

attached to this type of catheter, even after vigorous and repeated washings. Moreover, scanning electronmicroscopy of the incubated catheters showed that complete bacterial cells were attached to these tubes and overnight incubation of these washed catheters in LB broth gave positive cultures, suggesting that the bacteria still attached to the tubes remained viable. However, no attempts were made to quantitate the numbers of viable cells attached to the inner surfaces of the tubes. Furthermore, $K$. pneumoniae strain KMD11 showed a higher capacity for adherence to glass surfaces than strain KMD01 (fig. 3).

Because the interaction between bacterial cells and smooth surfaces may depend on the $p \mathrm{H}$, ionic strength and general composition of the fluid where the cells are suspended, normal human CSF was used in some of the determinations of adherence capacities; results similar to those shown in figs. 2 and 3 were obtained. 


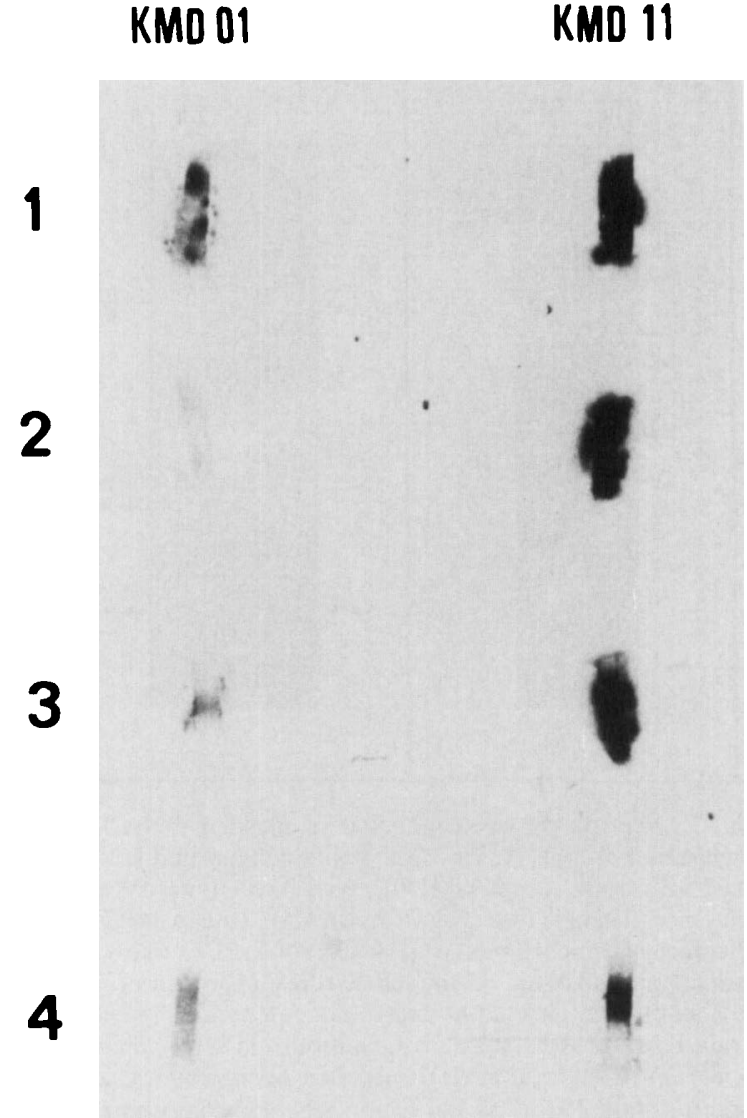

Fig. 2. Adherence of ${ }^{35} \mathrm{~S}$-labelled $K$. pneumoniae strains KMD01 and KMD1 1 to catheters of CSF shunts, assessed by autoradiography; 1 : without washing; 2 : after gentle washing; 3 : after one vigorous washing; 4 : after five vigorous washings (see Materials and methods).
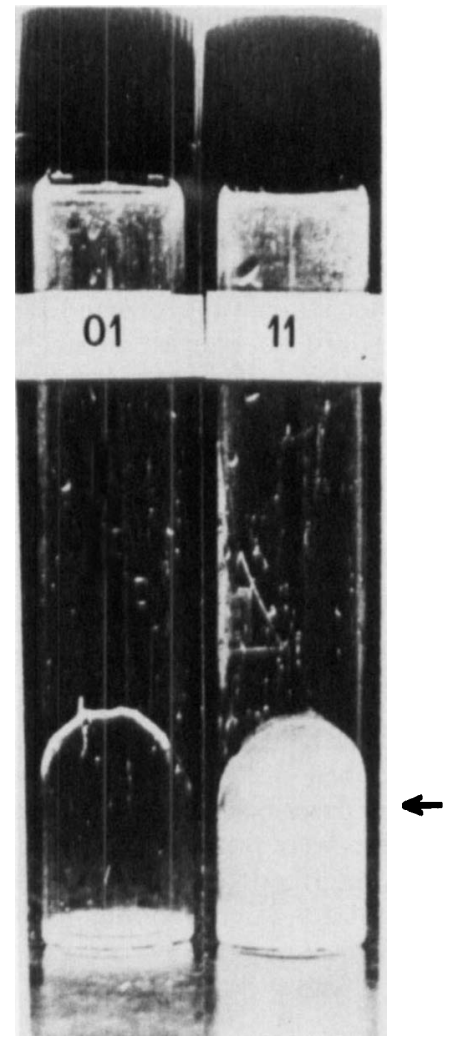

Fig. 3. Adherence of $K$. pneumoniae strains KMD01 (01) and KMD1 1 (11) to the walls of glass tubes. Adherent growth on the inner surface at the bottom of the tube is indicated by an arrow.

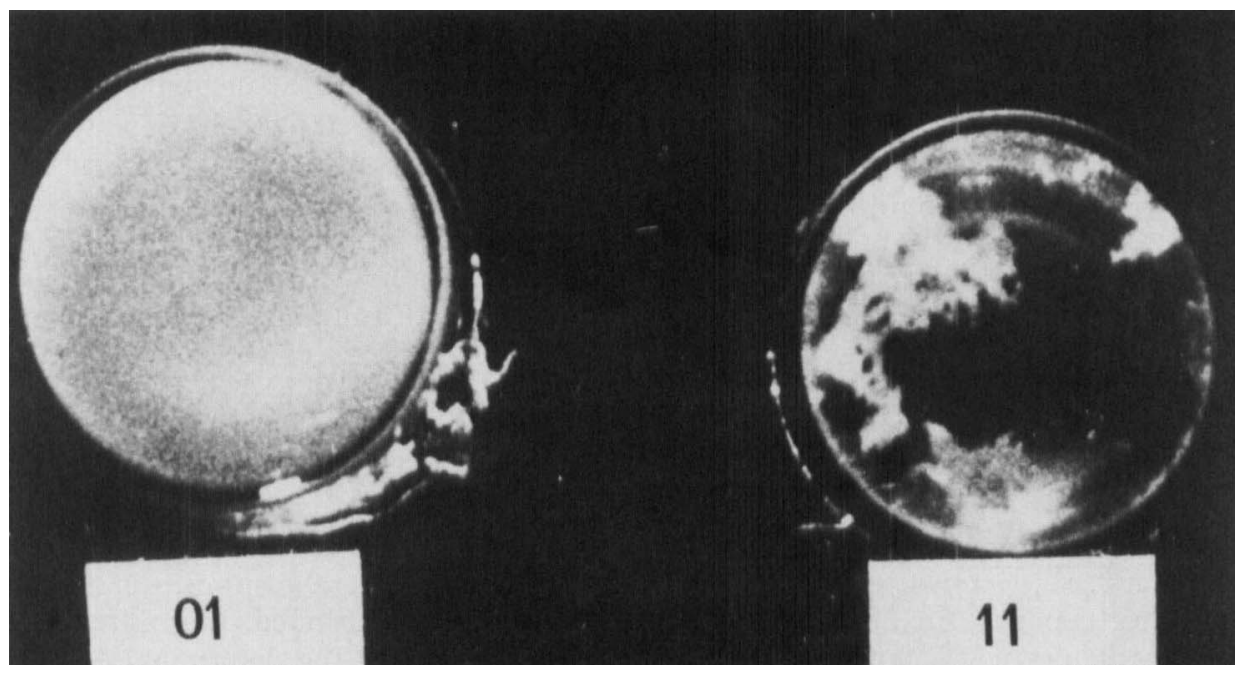

Fig. 4. Autoagglutination of $K$. pneumoniae strain KMD11 in minimal medium (right). Non-autoagglutinated KMD01 cells are shown for comparison (left). Tubes were photographed from the bottom. 


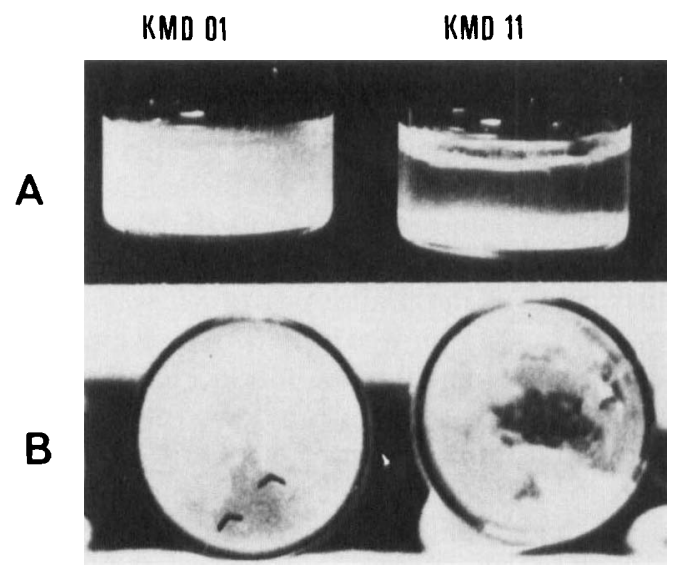

Fig. 5. Autoagglutination of Klebsiella strains KMD01 and KMDII grown in rich medium and resuspended in minimal medium. Strain KMD01 (left) developed a population of new non-agglutinated cells after incubation for $4 \mathrm{~h}$ in minimal medium (A: lateral view; B: bottom view). Autoagglutinated cells of strain KMD01 are indicated by two black arrowheads in the bottom view of this tube.

\section{Culture conditions and autoagglutination}

$K$. pneumoniae strain KMD11 autoagglutinated when cultivated in minimal medium (Davis medium), whereas the parent strain (KMD01) did not autoagglutinate (fig. 4). In contrast, neither strain showed any autoagglutination when grown in rich medium (LB broth). When the strains were grown to late exponential phase in LB broth, and were then harvested, washed, and resuspended in minimal medium, both cultures showed instantaneous autoagglutination. However, if after an appropriate dilution (see Materials and methods), cells were further incubated for $4 \mathrm{~h}$ in minimal medium, strain KMD01 developed a new population of non-agglutinated cells (fig. 5). These results suggest that strain KMD01 has the ability to modify its outer surface in response to a change of cultural conditions and prevent autoagglutination in minimal medium.

Fig. 6 shows that the banding patterns of membrane proteins from non-agglutinated cells grown in LB broth were very similar in both strains. However, when the protein profile from nonagglutinated bacteria (strain KMD01) grown in minimal medium was compared with that from autoagglutinated bacteria (strain KMD11) grown in the same medium, the presence of a polypeptide with an apparent mol. wt of $c .41 \times 10^{3}$ correlated with the absence of autoagglutination characteristic of strain KMD01.

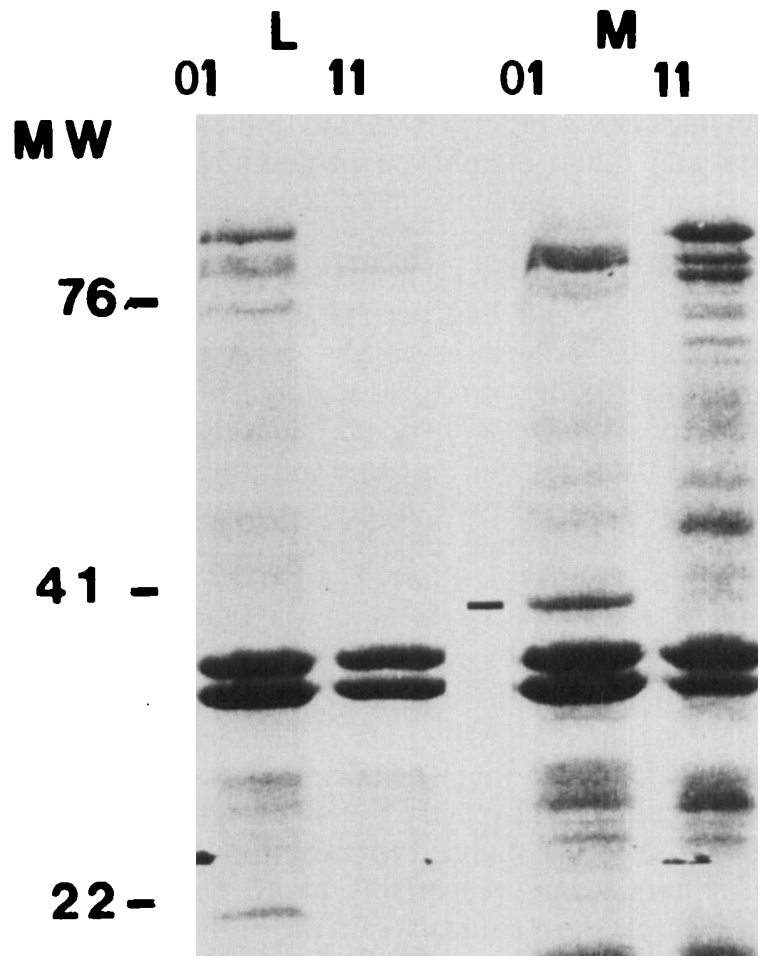

Fig. 6. SDS-polyacrylamide-gel electrophoresis of membrane proteins from strains KMD01 (01) and KMD11 (11) grown in LB broth (L) or in minimal Davis medium (M). MW $=$ mol. wt $\left(10^{3}\right)$. From LB broth, the profiles are similar; from minimal medium a polypeptide band of mol. wt c. $41 \times 10^{3}$ is present with KMD01 but not with KMDIl.

\section{Discussion}

A multiresistant strain of $K$. pneumoniae (KMD01), isolated from an infected CSF shunt, was compared with its in-vitro derivative (KMD11). The derivative was more adherent to the surface of V-P catheters, and it autoagglutinated when grown in minimal medium, whereas the parent strain (KMD01) did not. A protein with an apparent mol. wt of $c .41 \times 10^{3}$ was detected in membrane fractions from the non-agglutinated cells of strain KMD01 grown in minimal medium, but there was an absence of synthesis or incorporation of this protein in membrane fractions from autoagglutinated cells of strain KMD11 grown in the same medium.

The results suggest that the bacterial surface structures of these strains are different. Since strains KMD01 and KMD11 constitute a pair of isogenic strains, one with and one without a plasmid of mol. wt $85 \times 10^{6}$, the association of this plasmid with the phenotypic differences between the strains is 
strongly suggested. Interestingly, Skurnik et al. (1984) have recently described that autoagglutination in Yersinia spp. correlated with the synthesis of a specific outer-membrane protein. However, in that system the expression of the specific protein was associated with the presence of a virulence plasmid in the autoagglutinable strain, and the virulence plasmid has been associated also with epithelial cell adherence.

It is well known that nosocomial multiresistant strains of $K$. pneumoniae display a large diversity of plasmid profiles, and that many of these plasmids are exchanged between different strains with high frequency in defined environments such as the nosocomial ones (Datta et al., 1979; Denoya et al., 1981; Rubens et al., 1981). Similarly, the K. pneumoniae strain KMD11 described in this work has been obtained with a high frequency during culture of the parent strain KMD01 in vitro. The generation in nature of new variants of bacterial strains with a higher adherence capacity to V-P catheters and, by deduction, with enhanced colonisation effectiveness for shunts, seems reasonably likely. Such phenotypic acquisitions could explain the survival of some bacterial strains infecting implanted shunts, even after appropriate antimicrobial therapy (James $e t$ al., 1980). Other factors, also, could favour the adhesion and survival of bacteria in the catheters, such as $p \mathrm{H}$ and chemical alterations of the CSF, or a reduced flow of CSF, during shunt malfunction and infection; and structural irregularities in the inner

\section{REFERENCES}

Ayars G H, Altman L G, Fretwell M D 1982 Effect of decreased salivation and $\mathrm{pH}$ on the adherence of Klebsiella species to human buccal epithelial cells. Infection and Immunity 38:179-182.

Bauer A W, Kirby W M, Sherris J, Turck M 1966 Antibiotic susceptibility testing by a standardized single disk method. American Journal of Clinical Pathology 45:493-496.

Bayston R, Lari J 1974 A study of the sources of infection in colonized shunts. Developmental Medicine and Child Neurology 16 Suppl 32:16-19.

Bayston R, Penny S R 1972 Excessive production of mucoid substance in Staphylococcus SIIA: A possible factor in colonization of Holter shunts. Developmental Medicine and Child Neurology 27 Suppl: 25-28.

Birnboim H C, Doly J 1979 A rapid alkaline extraction procedure for screening recombinant plasmid DNA. Nucleic Acids Research 7:1513-1523.

Christensen G D, Simpson W A, Bisno A L, Bechey E H 1982 Adherence of slime-producing strains of Staphylococcus epidermidis to smooth surfaces. Infection and Immunity 37:318-326.

Christensen G D, Simpson W A, Bisno A L, Beachey E H 1983 Experimental foreign body infections in mice challenged surface of V-P catheters may permit microcolonies to anchor and hide (Guevara et al., 1981).

It has been demonstrated that fimbriae (pili) mediate adhesion of Klebsiella strains to mammalian epithelial cells and erythrocytes (Duguid and Old, 1980) and to plant roots (Korhonen et al., 1983). Less is known about the components and factors involved in the adhesion of Klebsiella cells to inert surfaces. Long hydrophilic extensions of the bacterial cell, like fibrous polysaccharides of the glycocalyx, and proteinaceous structures including flagella, pili and glycoprotein rods, have been assigned a possibly significant role during the first step of bacterial adhesion to smooth surfaces (Costerton et al., 1981). However, a detailed understanding of the adhesion of $K$. pneumoniae to V-P shunts cannot be assessed without further information.

The strains and experimental system described here seem to be suitable for further study of the molecular basis of such adherence. This type of study should also contribute towards the development of improved V-P catheters or therapy aimed at diminishing or eliminating bacterial adherence to CSF shunts. Meanwhile, the removal of an infected shunt, and its replacement with a new one after suitable antimicrobial therapy, seems advisable in order to avoid repeated infections.

We thank J. Guevara and G. Zuccaro for providing us with CSF catheters, and useful discussions, and A. Howard for expert secretarial assistance. with slime-producing Staphylococcus epidermidis. Infection and Immunity 40:407-410.

Costerton J W, Irvin R T, Cheng K J 1981 The role of bacterial surface structures in pathogenesis. CRC Critical Reviews in Microbiology 8:303-338.

Datta N, Hughes V M, Nugent M E, Richards H 1979 Plasmids and transposons and their stability and mutability in bacteria isolated during an outbreak of hospital infection. Plasmid 2:182-196.

Denoya C D, Trevisán A R, Zorzópulos J, Rubeglio E, Woloj M 1981 Detection and characterization of plasmids in clinical isolates of pathogenic bacteria. In: Crocomo, $\mathrm{O} J$ et al. (eds) Proceedings of the international symposium on genetic engineering, Sao Paulo, Brazil. pp 97-101.

Duguid J P, Old D C 1980 Adhesive properties of Enterobacteriaceae. In: Beachey E H (ed) Bacterial adherence (Receptors and recognition, series B, vol. 6). Chapman and Hall, London. pp 185-217.

Fader R C, Davis C P 1980 Effect of piliation on Klebsiella pneumoniae infection in rat bladders. Infection and Immunity 30:554-561.

Guevara J, La Torre J, Denoya C, Zuccaro G 1981 Microscopic studies in shunts for hydrocephalus. Child's Brain 8:284 293.

Isenberg H D, Washington J A, Balows A, Sonnenwirth A C 
1980 Collection, handling and processing of specimens. In: Lennette $\mathrm{E} \mathrm{H}$ et al. (eds) Manual of clinical microbiology, 3rd edn. American Society for Microbiology, Washington, D.C. pp 52-82.

James H E, Walsh J W, Wilson H D, Connor J D, Bean J R, Tibbs P A 1980 Prospective randomized study of therapy in cerebrospinal fluid shunt infection. Neurosurgery $7: 459$. 463.

Korhonen T K, Tarkka E, Ranta H, Haahtela K 1983 Type 3 fimbriae of Klebsiella sp.: Molecular characterization and role in bacterial adhesion to plant roots. Journal of Bacterio$\log y$ 155:860-865.

Laemmli U K 1970 Cleavage of structural proteins during the assembly of the head of bacteriophage T4. Nature 227:680685.

Macrina F L, Kopecko D J, Jones K R, Ayers D J, McCowen S M 1978 A multiple plasmid-containing Escherichia coli strain: convenient source of size reference plasmid molecules. Plasmid 1:417-420.

Maniatis T, Fritsch E F, Sambrook J 1982 Molecular cloning. A laboratory manual. Cold Spring Harbor Laboratory, Cold Spring Harbor, New York.

Peters G, Locci R, Pulverer G 1982 Adherence and growth of coagulase-negative staphylococci on surfaces of intravenous catheters. Journal of Infectious Diseases 146:479-482.

Rubens C E, Farrar W E., McGee Z A, Schaffner W 1981 Evolution of a plasmid mediating resistance to multiple antimicrobial agents during a prolonged epidemic of nosocomial infections. Journal of Infectious Diseases 143:170181 .

Schnaitman C A 1971 Effect of ethylenediaminetetraacetic acid, triton X-100, and lysozyme on the morphology and chemical composition of isolated cell walls of Escherichia coli. Journal of Bacteriology 108:553-563.

Schoenbaum S C, Gardner P, Shillito J 1975 Infections of cerebrospinal fluid shunts: Epidemiology, clinical manifestations, and therapy. Journal of Infectious Diseases 131:543552.

Skurnik M, Bölin I, Heikkinen H, Piha S, Wolf-Watz H 1984 Virulence plasmid-associated autoagglutination in Yersinia spp. Journal of Bacteriology 158:1033-1036.

Zorzópulos J, Trevisán A R, Denoya C D 1984 Deletions in Klebsiella pneumoniae $\mathrm{R}$ plasmids induced by growth in the presence of acridine orange at high temperature. Antimicrobial Agents and Chemotherapy 25:659-661. 